\title{
Improvement the Chemical Properties of Cassava Through Microbial Fermentation Using Rhizopus Oligosporus
}

\author{
Totok Prasetyo ${ }^{1, *}$, Ferry Ardhianto ${ }^{2}$, and Mayang Pawitra ${ }^{2}$, Siswo Sumardiono ${ }^{2}$ \\ ${ }^{1}$ Departement of Mechanical Engineering, Semarang State Polytechnic, Postal Code 50275, Semarang, Indonesia \\ ${ }^{2}$ Department of Chemical Engineering, Diponegoro University, 50275, Semarang, Indonesia
}

\begin{abstract}
Indonesia is the world's largest importer of wheat. Because of high wheat imported, Indonesia's researchers has seek an alternative to wheat-based local materials that having equivalent physicochemical properties. Potential alternative replacement of wheat flour is cassava. Cassava can be modified its rheology and physicochemical properties in order to be wheat equivalents. Cyanide contained in the cassava flour cannot be removed immediately by physical treatment. Several efforts have been made, such as soaking with saline solution, the addition of citric acid, and heating, showed a reduction in levels of cyanide in the flour. In this study, reduced levels of cyanide bound by converting it into protein using of Rhizopus oligosporus. While cyanide dissolved with the help of soaking with saline solution and buffer solution. In this case, use a buffer solution such as sodium sulphites which serves to change the form of cyanide dissolved into a form that is less toxic. In addition, a buffer solution $\mathrm{pH}$ also controls a range of 6 , because in this range of cyanide bound to be easier to dissolve. With the combination treatment is expected to be a reduction in the levels of cyanide and exhibited significantly increased levels of protein in cassava flour. Flour has a protein content of best nutritional protein at $3.68 \%$ dry basis. Cyanide reduction was highest in samples with high levels of Rhizopus oligosporus grated $1.5 \%(\mathrm{w} / \mathrm{w})$ as 72 hours, with a lag of $0.09(\mathrm{mg} / \mathrm{kg}$ ) cyanide. Flour with the best nutritional quality is obtained from fermentation with conditions: grated, 12 hours of fermentation as well as using Rhizopus oligosporus $3.5 \%(\mathrm{w} / \mathrm{w})$.
\end{abstract}

\section{Introduction}

Wheat (Triticum sp.) is a group of tribes cereals grains are rich in carbohydrates. Wheat flour is made with raw wheat and Indonesia to meet this need by importing 5.4 million tons of wheat and 680 thousand tons of wheat, with a nominal value of imports amounted to 15.5 trillion rupiah. Wheat flour is widely used as raw materials for various food products, such as noodles, cakes, breads, cookies, or other applications. One of the food commodities should be considered to be developed as an alternative use of wheat flour in Indonesia are tubers like cassava. Unlike wheat, cassava grows well in Indonesia. Data show that in Indonesia, cassava is grown around 1.4 million hectares per year, and its roots are used for food, feed and as raw material for starch extraction. Meanwhile, preliminary data obtained from BPS show that Indonesia cassava production in 2010 was 2.080 .853 tons $[9,33]$. The fact that can be found in the community that has been largely cassava by farmers only sold without being processed, so the price is very cheap. But actually if cassava is processed further to produce modified starch with a higher price [34]. This modification effort can certainly improve cassava farmers and encourage small and medium entrepreneurs as producer's cakes, bread, noodles, and others to develop. Processed cassava flour price is much cheaper than wheat flour from wheat.

Flour made from cassava could potentially be used as a replacement or substitute the use of wheat flour. Excess flour made from cassava flour is having a short chain, so it is easy to digest digestive system, does not cause allergic reactions in the body because it does not contain gluten, as well as cooking oil does not absorb excess oil. The main problem that arises is the amount of cyanogenic glucoside content of compounds in the cassava flour is equal to $62 \mathrm{mg}$ [1] which have a tendency as a poison. In Indonesia, cyanide levels in cassava flour allowed by BPOM is $40 \mathrm{ppm} /$ unit weight. Value levels far above the standard FAO / WHO, 2010 in the amount of $10 \mathrm{ppm} /$ unit weight.

Previous researcher revealed that the bound cyanide contained in the cassava flour cannot be removed immediately by physical treatment. Some efforts have been made, such as soaking with saline solution, the addition of citric acid, and heating, showed a reduction in levels of cyanide in the flour $35 \mathrm{w} / \mathrm{w}$. Other

Corresponding author: tprasetyo06@yahoo.com 
researchers, reveals something else about his research on cassava. His research concluded that by varying the method of drying and drying temperature on fermented cassava cyanide levels lagged obtained a minimum of $30.35 \mathrm{w} / \mathrm{w}$. Then Owuamanam conducted a study with cassava soaking with water at $\mathrm{pH} 8$ for 72 hours with citric acid. This treatment is getting late for $39.28 \mathrm{mg} / \mathrm{kg}$ $\mathrm{HCN}$ levels. The above research was focused on removing cyanide levels without improving nutrition flour produced.

Cassava can be modified its rheology and physicochemical properties in order to be wheat equivalents. Cassava starch modification, which involves the alteration of the physicochemical characteristics of the native starch to improve better paste clarity, gel stability, increased resistance to retrogradation, increased solubility and improved freeze-thaw stability, which improves their application as stabilizers, fillers, binders, adhesives, and its functional characteristics, can be used to tailor starch to specific food applications [2-4, 8, 13, 18-23, 24, 26, 29, 31-32, 35-36].

The fermentation and sun-drying or UV irradiation processes produce cassava depolymerization [16] which is correlated with expansion ability [6-7, 17]. Sour cassava starch (Polvilho azedo) is a naturalfermented and sun-dried cassava starch that shows expansion properties during baking. However, acidification of cassava starch with lactic, acetic, or butyric acid (10-11, 30], followed by oven drying, failed to produce any great expansion ability after baking. Similarly, amylase depolymerization [10] or natural lactic fermentation [16] did not afford expansion properties to cassava starch. Consequently, it has been suggested that the expansion properties of sour cassava starch result, at least in part, from the combined effect of starch fermentation and sundrying [12, 15-16, 25, 30].

In laboratory studies, cassava starch acidified with lactic acid and subjected to UV irradiation expanded during baking [5-6, 12, 15, 17]. Thus, expansion could be a result of the photochemical treatment. However, in contrast to UV-irradiated cassava starch, UV-irradiated corn starch showed no expansion during baking [5]. The structural changes involved in the transformation of sour cassava starch dough are not clearly understood. Besides the natural fermentation in tanks which normally used approximately 30 days, soaking in $1 \%(\mathrm{w} / \mathrm{w})$ lactic acid solution for 15-30 min was also studied [14, 27-28]. Direct irradiated with artificial UV source was applied to the sour cassava starch. The oxidative modification of cassava starch with lactic acid together with either sun dried or UV proved to obtain baking characteristic of an increase specific volume of tested biscuits. However, this behavior did not show in sour cassava starch treated under oven-drying method [30].

In this study, reduced levels of cyanide bound by converting it into protein using of Rhizopus oligosporus. While cyanide dissolved with the help of soaking with saline solution and buffer solution. In this case, use a buffer solution such as sodium sulphites which serves to change the form of cyanide dissolved into a form that is less toxic. In addition, a buffer solution $\mathrm{pH}$ also controls a range of 6 , because in this range of cyanide bound to be easier to dissolve. With the combination treatment is expected to be a reduction in the levels of cyanide and exhibited significantly increased levels of protein in cassava flour.

\section{Material and Methods}

Cassava has acquired from the estate then peeled the skin and washed under running water. This treatment is in addition to remove dirt still attached, can also eliminate some of cyanide contained in the outer surface of the cassava. Soaking with salt and mixing grated cassava with buffer concentration. Cassava has been washed and soaked with saline solution and a buffer solution $\left(\mathrm{Na}_{2} \mathrm{SO}_{3}\right)$. Soaking done in a vessel containing a solution of each salt and buffer to a concentration of $2 \%$ $\mathrm{w} / \mathrm{w}$. Soaking do in each solution was performed for 1 hour. After soaking cassava is ready to be fermented with Rhizopus oligosporus. After a thorough soaking, cassava is then divided into two variables, the form of chips and grated. Then each variable is taken 250 grams for fermented in the fermentor with the help of Rhizopus oligosporus. Used Rhizopus oligosporus use of three variables, ie $1.5 \mathrm{w} / \mathrm{w}, 2.5 \mathrm{w} / \mathrm{w}$ and $3.5 \mathrm{w} / \mathrm{w}$. Each period of 12 hours, 24 hours, 36 hours, 48 hours, 60, and 72 hours, samples harvested.

Fermentation yields then dried using sunlight. Drying is carried out by using sunlight for 2 to 3 days. Flour and sieving fermented cassava that has been dried is then transformed into flour using a blender or food processor. Results have been obtained and sifted, to obtain flour with size of 60 mesh.

Qualitative analysis of cyanide used in testing, the testing principle of $\mathrm{HCN}$ - soluble in water, in the heat and acid $\mathrm{HCN}$ will evaporate, and $\mathrm{HCN}$ vapor reacts with picric acid to form a red color. Quantitative analysis can be done by spectrophotometryc analysis. The working principle of this method is the cyanide in the sample is converted into cyanogen chloride $(\mathrm{CNCl})$ reacts with Chloramin $\mathrm{T}$ at a $\mathrm{pH}$ less than 8 hydrolyzed to cyanate. After reacting perfectly, $\mathrm{CNCl}$ forming red blue with barbituric acid in pyridine and color happens to read at a wavelength of 578 nanometers.

\section{Results and Discussion}

Sample form is one of the factors that can influence the process of linamarin breakdown during fermentation. In the experiment, tested forms of chips and grated against the final cyanide levels in cassava flour. Of the three graphs above in the Figure 1, Figure 2 and Figure 3, it can be seen that the cassava flour with grated good form with a concentration of $1.5 \%$ by weight Rhizopus oligosporus up to $3.5 \%$ by weight, resulting in levels of cyanide which is less than the cassava flour in the form of chips. That is because the contact surface on the grated surface area larger than the chips. In the process of solving linamarin with the help of a buffer solution to maintain a neutral $\mathrm{pH}$, the greater 
the surface area of contact, the easier linamarin to rupture and produce aspartate.

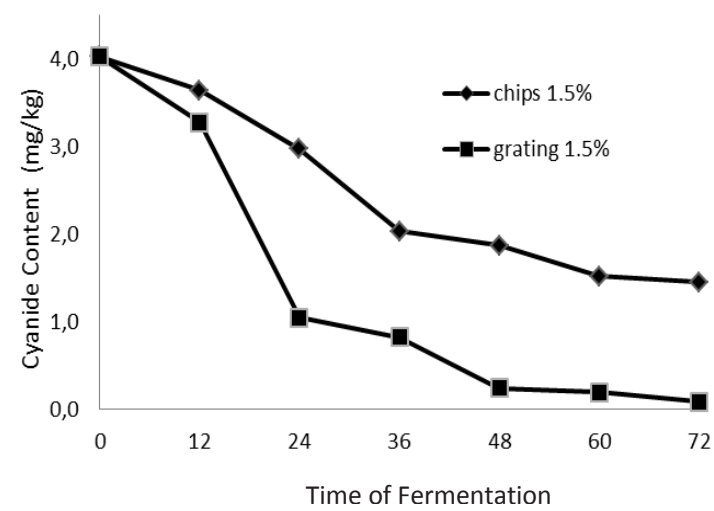

Fig 1. Cyanide content as function of time fermentation with variable chip and grating cassava for Rhizopus oligosporus concentration $1.5 \%(\mathrm{w} / \mathrm{w})$

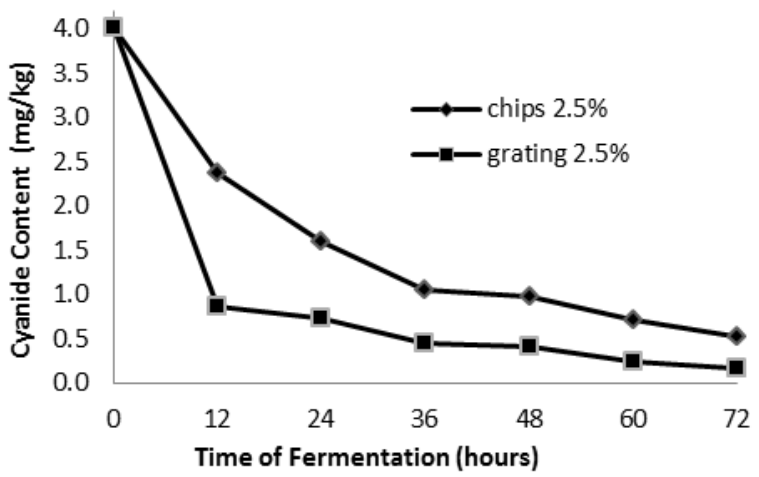

Fig 2. Cyanide content as function of time fermentation with variable chip and grating cassava for Rhizopus oligosporus concentration $2.5 \%(\mathrm{w} / \mathrm{w})$

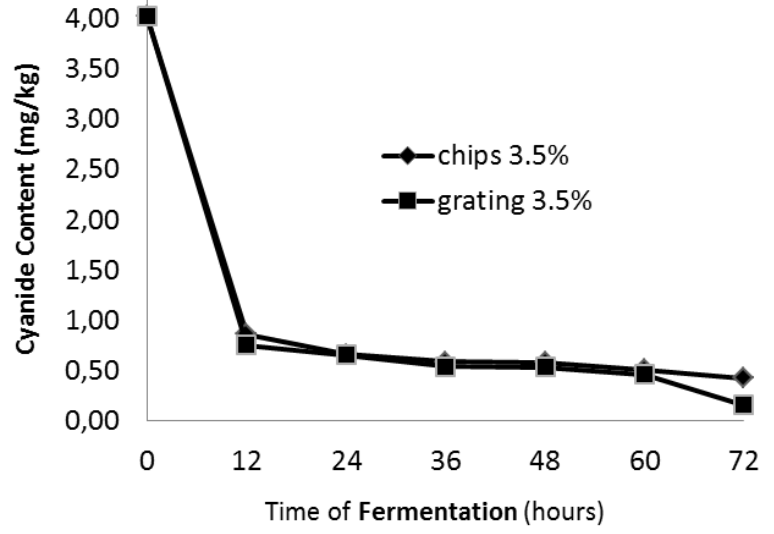

Fig 3. Cyanide content as function of time fermentation with variable chip and grating cassava for Rhizopus oligosporus concentration $3.5 \%(\mathrm{w} / \mathrm{w})$

Figure 4 and Figure 5 is the \% of Rhizopus oligosporus as a factor affecting the final level of cyanide in cassava flour. From the figures can be seen that for both types of cassava flour (in the form of grated and chips) cyanide levels decreased significantly. From graphics chips, it can be seen that the greater percent of Rhizopus oligosporus, the lower levels of cyanide were left behind. This phenomenon is also found in cassava flour in a grater. That is because the more weight percent of Rhizopus oligosporus is used, the more the enzymes produced in the fermentation. Small levels of cyanide showed that regardless how much cyanide is converted into proteins.

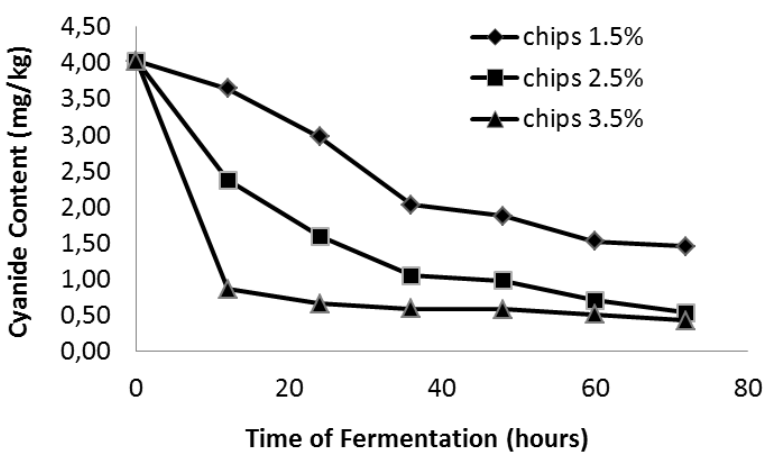

Fig 4. Cyanide content as function of time fermentation of chip cassava with variable Rhizopus oligosporus concentration

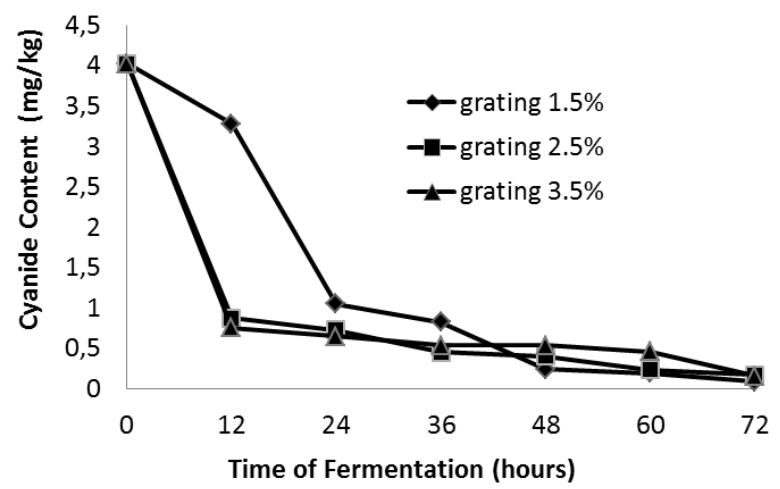

Fig 5. Cyanide content as function of time fermentation of grating cassava with variable Rhizopus oligosporus concentration

Mold has a short life cycle, as well as Rhizopus oligosporus we use has survival up to 72 hours. If the fermentation is carried out over time, the results will not be too much of a difference. It is caused by a fungus that has entered the phase of stagnation, meaning that the amount of mold that life equal to the number of dead mold. This means that energy use will remain the same after this phase occurs. So the reduction of cyanide after 72 hours will not have much difference. Maximum decrease obtained for the forms of chips is 0.423 $(\mathrm{mg} / \mathrm{kg})$, while the form of grated $0.09(\mathrm{mg} / \mathrm{kg})$.

In the Figure 6, Figure 7, and Figure 8 above, were described relations protein content obtained with different forms of media. The chart shows, the use of media chips produce higher protein than using media grate, either on the use of $1.5 \%(\mathrm{w} / \mathrm{w}), 2.5 \%(\mathrm{w} / \mathrm{w})$ or $3.5 \%$ (w / w) Rhizopus oligosporus. Grated media has advantages in a more rapid decomposition of cyanide. But in terms of the formation of the protein, the opposite 
occurs. Media chips are more porous, as there are cavities in the media that facilitates the diffusion of air into and out of the media. This provides an advantage in the metabolism of Rhizopus oligosporus, because it is an aerobic organism. Better metabolic enzymes will produce more protein to form cyanide decomposition. Decomposed of cyanide in the media chips is less, but more optimally utilized for conversion into protein, so the protein produced.

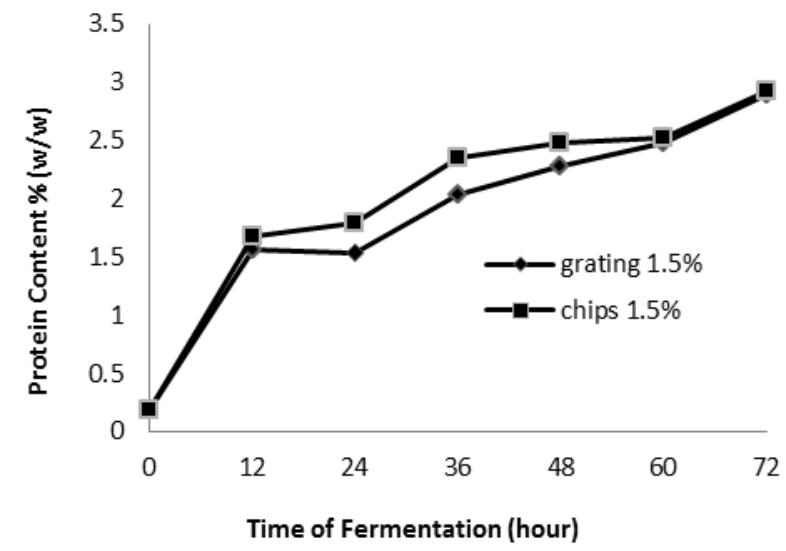

Fig 6. Protein content as function of time fermentation with variable chip and grating cassava for Rhizopus oligosporus concentration $1.5 \%(\mathrm{w} / \mathrm{w})$

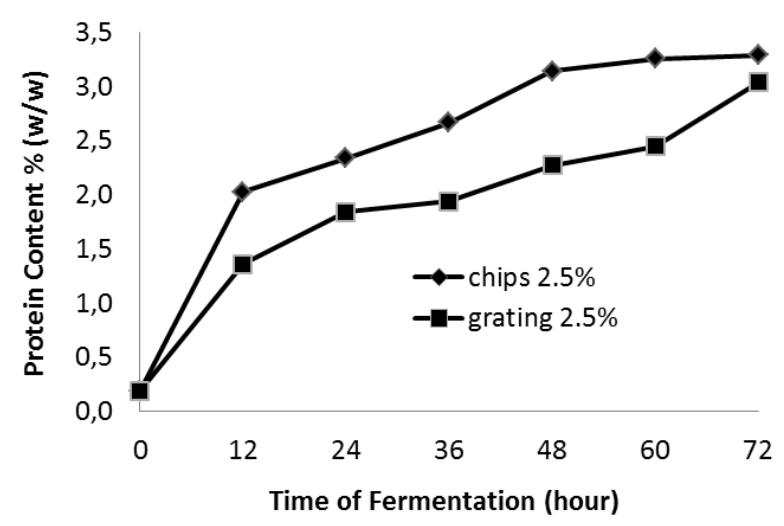

Fig 7. Protein content as function of time fermentation with variable chip and grating cassava for Rhizopus oligosporus concentration $2.5 \%(\mathrm{w} / \mathrm{w})$

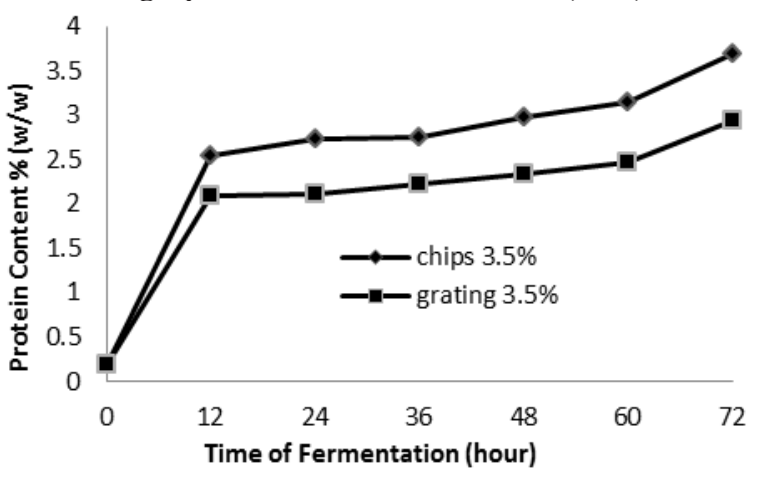

Fig 8. Protein content as function of time fermentation with variable chip and grating cassava for Rhizopus oligosporus concentration $3.5 \%(\mathrm{w} / \mathrm{w})$
Rhizopus were inoculated into the substrate affects the proteins produced. It can be seen from the Figure 9 and Figure 10 above, an increase in levels of the protein were obtained. Mold serves as a producer of enzymes that function in converting cyanide that has been released into amino acids [1]. This enzyme breaks down acetone sianohidrin, in order to obtain the final form of the amino acid aspartate and $\mathrm{NH}_{3}$. Thus, the more molds were added to the substrat, will be the more enzyme is produced, the more protein is formed.

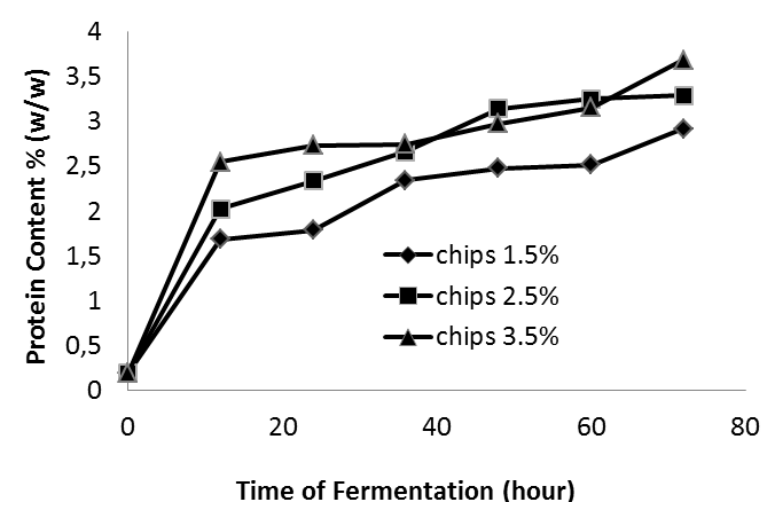

Fig 9. Protein content as function of time fermentation of chip cassava with variable Rhizopus oligosporus concentration

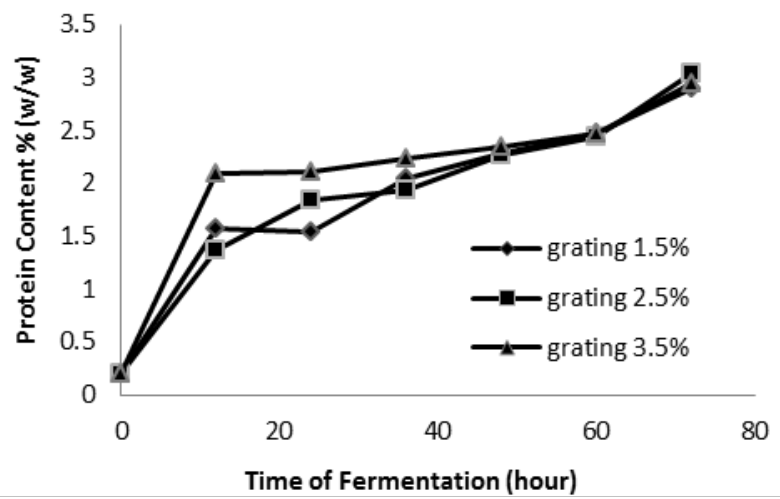

Fig 10. Protein content as function of time fermentation of grating cassava with variable Rhizopus oligosporus concentration

Optimum operating conditions can be seen from the data, by comparing the parameters behind the cyanide levels at least as well as the highest protein content in the samples that have been soaked in a solution of salt and buffer before. From the above data in the Table 1 can be concluded that by comparing the nutrition standards in accordance with the WHO reference parameter and flour, the best nutritional quality obtained from fermentation is in the conditions: grated, 72 hours of fermentation, and using $3.5 \%$ (w/w) Rhizopus oligosporus [17]. 
Table 1. Comparison cyanide and protein content of various experiments

\begin{tabular}{lcc}
\hline Cassava Flour & $\begin{array}{c}\text { Cyanide } \\
\text { Content } \\
\text { (mg/kg) dry } \\
\text { basis }\end{array}$ & $\begin{array}{c}\text { Protein } \\
\text { Content } \\
\text { (\%) dry } \\
\text { basis }\end{array}$ \\
\hline Cassava (control) & 4.03 & 0.19 \\
Cassava chip (72 hours & 0.42 & 3.69 \\
fermentation, 3.5\% \\
(w/w) R. Oligosporus \\
Cassava grating (72 \\
$\begin{array}{l}\text { hours fermentation, } \\
1.5 \% \quad \text { R.w) }\end{array}$ \\
Oligosporus
\end{tabular}

\section{Conclusions}

.Cassava flour with the best protein content has protein content of $3.69 \%$ d.b. The largest reduction of cyanide is in grated samples with Rhizopus oligosporus $1.5 \%$ weight level at 72 hours, with 0.09 ppm left. Cassava flour with the optimum result is obtained from fermentation with the conditions: grated with 12 hours of fermentation, and use $3.5 \%$ weight Rhizopus oligosporus.

\section{Acknowledgments}

The authors are grateful thank to Diponegoro University for financial support of this research with scheme International Research and Publication Grant.

\section{References}

1. M.N. Adindu, F.F. Olayemi, O.U. Nze-Dike, J. Food Composition and Analysis. 16, 21-24 (2003)

2. A.S. Ahmed, U.E. Igbo, C.C. Igwe, Nigerian Food J. 23, 85-90 (2005)

3. N.J. Alummoottil, S. Korappati, S.S. Moothdasseri, R. Revamma, N.M. Subbramoney, Starch/ Stärke. 57, 11, 547-555 (2005)

4. P. Tomasik, C.H. Schilling, Advances in Carbohydrate Chemistry and Biochemistry. 59, 175-403 (2004)

5. A.C. Bertolini, C. Mestres, P. Colonna, D. Lerner, G.D. Valle, Comprehensive studies of molecular changes occurring in sour cassava starch. In: Biopolymer Science: Food and Non Food Applications. INRA: Montpellier, France. 91, 8791 (1998).

6. A.C. Bertolini, C. Mestres, P. Colonna, Starch. 52, 340-344 (2000)

7. A.C. Bertolini, C. Mestres, C. Lourdin, G.D. Valle, P. Colonna, J. Sci. Food Agric. (2001)

8. R.N. Tharanathan, Food Science and Nutrition. 45, 371-384 (2005)

9. Badan Pusat Statistik (BPS). Tanaman Pangan. diakses dari http://www.bps.go.id/ . (2011)

10. C. Camargo, P. Colonna, A. Buleon, D. RichardMolard, J. Sci. Food Agric. 45, 273-289 (1988)
11. O. S. Cardenas, T.S. Buckle, J. Food Sci. 45, 15091528, (1980)

12. M.P. Cereda, O.L.S. Nunes, A. Westby, Brazilian fermented cassava starch. I. Production and use. XVI International Carbohydrate Symposium, Paris. 688 (1992).

13. S.G. Choi, W.L. Kerr, Effects of chemical modification of wheat starch on molecular mobility as studied by pulsed ${ }^{1} H$ NMR, LebensmittelWissenchaft und Technologie. 51, 1-8 (2003)

14. I.M. Demiate, N. Dupuy, J.P. Huvenne, M.P. Cereda, G. Wosiacki, Carbohydrate Polymers. 42, 149-158 (2000)

15. D. Dufour, S. Larsonneur, F. Alarcon, C. Brabet, Cassava flour and starch; Centro Internacional de Agricultura Tropical: Cali, Colombia. 133-142 (1996)

16. D. Dufour, Starch: Structure and Functionality, The Royal Society of Chemistry:Cambridge, U.K. 42-50 (1997)

17. I. Pudjihastuti, S. Sumardiono, Pengembangan proses inovatif kombinasi reaksi hidrolisis asam dan reaksi photokimia UV untuk produksi pati termodifikasi dari tapioka, Prosiding Seminar Nasional Kejuangan Teknik Kimia UPN, Yogyakarta. (2011)

18. A.M. Hermansson, K. Svegmark, Trends in Food Science and Technology. 7, 345-353 (1996)

19. J. Jane, J. Macromolecular Science, Part A. 32, 4, 751-757 (1995)

20. H. R. Kim, A.M. Hermansson, C.E. Eriksson, Starch. 44, 111-116 (1992).

21. H.R. Kim, P. Muhrbeck, A.C. Eliasson, J. Sci. Food Agric. 61, 109-116 (1993)

22. C.C. Seow, K. Thevamalar, Starch/Stärke. 45, 8588 (1993)

23. H. Liu, L. Ramsden, H. Corke, Carbohydrate Polymers. 40, 175-182 (1999a)

24. H. Liu, L. Ramsden, H. Corke, Starch/Stärke. 51, 249-252 (1999b)

25. C. Mestres, O. Boungou, N. Akissoe, N. Zakhia, J. Sci. Food Agric. 80, 665-672 (2000)

26. J.M.N. Miller, Starch/Stärke. 49, 4, 127-131 (1997)

27. N. Vatanasuchart, O. Naivikul, S. Charoenrein, K. Sriroth, Kasetsart J. (Nat.Sci.). 37, 334-344 (2003)

28. N. Vatanasuchart, O. Naivikul, S. Charoenrein, K. Sriroth, Carbohydrate Polymers. 61, 80-87 (2005)

29. C. Perera, R. Hoover, A.M. Martin, Food Research Int'1. 30, 235-247 (1997)

30. M. Plata-Oviedo, C. Camargo, J. Sci. Food Agric. 77, 103-108 (1998)

31. J. Singh, L. Kaur, O.J. McCarthy, Food Hydrocolloids. 21, 1-22 (2007a)

32. J. Singh, L. Kaur, O.J. McCarthy, Food hydrocolloids. 21, 1-22 ((2007b).

33. S. Sumardiono, I. Pudjihastuti, B. Jos, M. Taufani, F. Yahya, Modification Of Cassava Starch Using Combination Process Lactic Acid Hydrolysis And Micro Wave Heating To Increase Coated Peanut Expansion Quality. AIP Conference Proceedings. 1840,060005 (2017) 
34. S. Sumardiono, I. Pudjihastuti, Budiyono, H. Hartanto, I.C. Sophiana, Combination Process Method Of Lactic Acid Hydrolysis And Hydrogen Peroxide Oxidation For Cassava Starch Modification. AIP Conference Proceedings 1840,060006 (2017)

35. S. Sumardiono, R.B. Rakhmawati, Advanced Science Letters. 23, 6, 5789-5791 (2017)

36. S. Sumardiono, M. Djaeni, B. Jos, I. Pudjihastuti, M. Abdallatif, Advanced Science Letters. 23, 6, 5792-5795 (2017) 